\title{
PROCES MEDIACJI. TYPOLOGIA UCZESTNIKÓW I SZANSE POROZUMIENIA
}

\section{WPROWADZENIE}

Mediacja jest alternatywnym dla tradycyjnego postępowania sądowego sposobem rozwiązywania sporów i konfliktów. Jako procedura zrodzona z szacunku do człowieka pozwala na uznanie jego indywidualności i wyjątkowości oraz prawa do niezależności w podejmowaniu decyzji. Podejmując ważne decyzje życiowe w trakcie mediacji, uczestnicy nie tylko poddają refleksji swoje dotychczasowe postępowanie wobec drugiej strony konfliktu, ale też biora na siebie odpowiedzialność za podjęte zobowiazzania co do przyszłych działań, czyli uwzględniają swoją zdolność ich wypełnienia oraz przewidywane przyszłe ich efekty.

Kiedy los każdego aktora zależy od niego samego i od działań podjętych przez pozostałych aktorów sytuacji, mówimy o sytuacji współzależności ${ }^{1}$. Współzależność jest nieodłącznym atrybutem negocjacji. Taki charakter ma uczestniczenie w podejmowaniu decyzji o sposobie rozwiązania konfliktu czy sporu. John W. Thibaut i Harold H. Kelley ${ }^{2}$ pokazali, że działania innych ludzi sa źródłem wzmocnień, których wymiana występuje w trakcie każdej interakcji. To, jakim wynikiem zakończy się sytuacja, zależy od zachowań obydwu stron. W psychologii współzależność społeczna ujmowana jest czasem jako gra, w której każdy daży do maksymalizacji swojego interesu ${ }^{3}$. Ludmiła Rycielska i Piotr Rycielski, pisząc o kooperacji w sytuacjach dylematu, pokazuja, że jednostka może wybrać strategię kooperacji, myśląc o zysku wspólnym, albo strategię rywalizacji w celu maksymalizowania indywidualnego zysku. W takim przypadku, gdy człowiek odstępuje od kooperacji, powiększa swój własny zysk, ale kiedy wszyscy uczestnicy dylematu kooperuja, wspólny zysk jest maksymalizowany ${ }^{4}$.

Janusz Grzelak zwraca uwagę, że zgodnie z teorią orientacji społecznych ${ }^{5}$ człowiek nie zawsze działa dla maksymalizowania swoich dóbr, a w sytuacji

1 J. Grzelak, Motywacja w sytuacjach wspótzależności interesów, w: A. Szuster, D. Rutkowska (red.), O różnych obliczach altruizmu, Scholar, Warszawa 2008, s. 100.

2 J. W. Thibaut, H. H. Kelley, The Social Psychology of Groups, Wiley, New York 1959.

${ }^{3}$ Rozwój psychologicznych koncepcji współzależności jest związany z matematyczną teoria gier - J. Neuman von, O. Morgenstern, Theory of Games and Economic Behavior, Princeton Univ. Press, Princeton 1944.

${ }^{4}$ L. Rycielska, P. Rycielski, Kooperacja $w$ dylematach społecznych-efekty wptywu i perswa$z j i$, w: A. Szuster, D. Rutkowska (red.), O różnych obliczach altruizmu, Scholar, Warszawa 2008, s. 144 .

${ }^{5}$ Za jednego z prekursorów orientacji społecznych uważa się Charlesa McClintocka C. G. McClintock, Social motivation - a set of propositions, „Behavioral Science” 17(5), 1972, s. 438- 
współzależności celem aktora sytuacji - poza maksymalizacją korzyści własnych (indywidualizmem) - może być maksymalizacja: „[...] zysków partnera (altruizm), własnej przewagi nad partnerem (rywalizacja), łącznych zysków własnych i partnera (kooperacja), strat własnych (masochizm), strat partnera (agresja), łacznych strat własnych i partnera (sadomasochizm), przewagi strat własnych nad stratami partnera (męczeństwo)" ${ }^{6}$. Jak pokazuje J. Grzelak, wymienione orientacje społeczne - indywidualistyczna (rywalizacyjna), prospołeczna (altruistyczna i kooperacyjna) - mają znaczenie dla przetwarzania informacji o świecie społecznym, dla przypisywania wartości sytuacji oraz partnerom interakcji, dla podejmowanych działań i zachowania w sytuacji konfliktu, manewrowania między interesem własnym a interesem partnera. Autor podkreśla, że na percepcję sytuacji i zachowanie się w niej wpływaja „orientacje kontroli” i są one niezależnym od zysków z interakcji źródłem satysfakcji?

Janusz Reykowski podnosi, że zachowanie człowieka w sytuacji sprzeczności interesów i wartości jest determinowane przez kompetencje umysłowe, poznawcze i osobowościowe do przyjmowania racjonalnego nastawienia i umiejętności widzenia perspektywy drugiego, a funkcjonowanie ludzi zmienia się w zależności od kontekstu, w jakim działają ${ }^{8}$. Poznawcze funkcjonowanie ludzi może się więc zmieniać ze względu na sytuacyjne czynniki. Te same osoby mogą wykazywać różne orientacje w zależności od tego: jakie dobra są dzielone, w jaki sposób się o nich komunikuje, ile osób bierze udział w ich podziale, jaki dystans psychologiczny wykazuja te osoby. Istotną rolę odgrywają też: oswojenie się z sytuacja, stopień zaznajomienia z zadaniem, dostarczenie wzorów działania oraz jakość przekazanych instrukcji. Znaczenie ma również możliwość wsparcia ze strony osób, które reprezentuja wyższy poziom funkcjonowania, i obserwowanie ich ${ }^{9}$. Taką osobą w rozmowach mediacyjnych może być mediator wspierajacy negocjacje stron, który jest wzorem komunikowania się. Stara się on umożliwić ludziom nadanie sensu temu, co się dzieje w nich i wokół nich, zrozumieć wszelkie okoliczności podtrzymujące konflikt, znaleźć uzasadnienie swoich zachowań i podejmowanych decyzji.

\section{METODOLOGIA}

Od 2002 r. jestem mediatorem i postanowiłam poddać badaniom prowadzone mediacje. Wysłuchiwałam wypowiedzi ponad stu dwudziestu zwaśnionych stron, zarówno w trakcie mediacji, jak i po jej zakończeniu. Poczyniłam

454; D. M. Messick, C. G. McClintock, Motivational basis of choice in experimental games, „Journal of Experimental Social Psychology" 4(1), 1968, s. 1-25; zob. tė̇ J. Ł. Grzelak, Preferences and cognitive processes in interdependence situations: a theoretical analysis of cooperation, w: V. Derlega, J. Ł. Grzelak (eds.), Living with Other: Theories and Research on Cooperation and Helping Behavior, Academic Press, New York 1982, s. 97-127; J. Ł. Grzelak, Homo oeconomicus uspołeczniony? Motywacyjne i poznawcze uwarunkowania działania $w$ interesie społecznym, „Studia Psychologiczne” 26, 1988, s. 5-30; P. A. M. Van Lange, Beyond self-interest: a set of propositions relevant to interpersonal orientations, „European Review of Social Psychology” 11(1), 2000, s. 297-331.

${ }^{6}$ J. Grzelak, Motywacja..., s. 103-104.

7 Ibidem, s. 107-108.

8 J. Reykowski, Deliberatywna debata jako metoda demokratycznego rozwiazywania problemów - podejście empiryczne, w: K. Skarżyńska, U. Jakubowska, J. Wasilewski (red.), Konflikty międzygrupowe. Przejawy, źródta i metody rozwiazywania, Wyd. WSPS „Academica”, Warszawa 2007, s. 338.

9 J. Reykowski, Motywacja..., s. 339. 
pewne obserwacje dotyczące przebiegu mediacji, zachowań skonfliktowanych osób, zachowań mediatora. Doszłam do wniosku, że mediacja jest przestrzenią społeczna, w której zachodzą różnorodne procesy, manifestowane są różne postawy i osiagane różne cele. W swoich analizach przyjęłam hermeneutyczną postawę badawcza (dająca zgodę na rozumienie i interpretację) oraz podejście fenomenograficzne, pomocne w poznawaniu doświadczania tego zdarzenia życiowego i jego rezultatów. Zadbałam, by opisywane przez badanych fragmenty życia podlegały ich subiektywnej interpretacji. Badane procesy mediacyjne były spotkaniem poszkodowanych (ofiar) i sprawców (krzywdzicieli) powiązanych toczącym się w ich sprawie postępowaniem przed sądem. Ponieważ dokumentacja sądowa była mi dostępna, dokładnie zapoznałam się z nią, skupiając się głównie na: treści wyroków i okoliczności zawarcia ustaleń zakończonych ugodą mediacji w orzeczeniu sądu; zagrożeniu ustawowym wynikającym z przepisów prawa i zasądzonym wymiarze kary; informacji, czy wskazany przez sąd jako oskarżony był ponownie karany, czyli czy po mediacji i zakończonej sprawie karnej wszedł ponownie w konflikt z prawem.

Przebieg każdej mediacji był inny. Używając języka symbolicznego interakcjonizmu Ervinga Goffmana ${ }^{10}$, można powiedzieć, że były to sytuacje o swoistej dramaturgii i rozgrywały się na wspólnej dla aktorów scenie. Każdy znał swoją rolę - mediator „reżysera”, a zwaśnione strony „bohaterów dramatu” - mimo że przebieg akcji nie był ograniczany ścisłymi wskazówkami co do odgrywania ról. Współuczestnicy „przedstawienia” mogli swobodnie komunikować się ze sobą we właściwy sobie sposób i stosować dowolne środki wyrazu. Zawężenie rozmów do kwestii mających związek z zaistniałym incydentem (z powodu którego sprawa trafiła do sądu) sprawiało, że wszyscy starali się poruszać w ich obrębie. Czas spektaklu (mediacji) nie był ograniczony i trwał dopóty, dopóki wszyscy uczestnicy sytuacji wyrażali na to zgodę. Opisywane mediacje rozgrywały się we wspólnym dla uczestników czasie i miejscu. W rezultacie przeprowadzonych badań jakościowych zebrałam materiał, który odsłonił wiele obrazów interakcji i oczekiwanych przez uczestników mediacji efektów, a także pozwolił mi na wyłonienie czterech typów negocjatorów. Zaproponowana typologia miała stać się inspiracją dla praktyków i przedmiotem dyskusji, dlatego zdecydowałam się spotkać z innymi mediatorami, by skonsultować stworzoną typologię. W celu dotarcia do istoty zjawiska i otrzymania informacji przeprowadziłam pogłębione wywiady indywidualne: in-depth interview (IDI). Dzięki temu uzyskałam szczegółowe opinie i informacje od ekspertów w dziedzinie mediacji, którzy zwrócili moją uwagę na istotne dla nich kwestie.

\section{ZALOŻENIA I PRZEBIEG MEDIACJI}

Podejmujac analizę procesu mediacji, starałam się dostrzec tworzaccą się $\mathrm{w}$ jej ramach przestrzeń społeczną i psychologiczna, kiedy to skonfliktowane osoby spotykają się w celowo zaaranżowanej sytuacji. Każda z nich ma swoje interesy, które chce zrealizować, a podejmowane przez nie działania zmierzają

\footnotetext{
${ }^{10}$ E. Goffman, Forms of Talk, Univ. of Pennsylvania Press, Philadelphia 1981.
} 
do oczekiwanego rezultatu i wzajemnie się dopełniają. Uczestnicy nawiązuja różnorodne interakcje, różnie przeżywają takie spotkania, szukają pomocy, porady, odkrywają siebie, uczą się, co skutkuje różnego rodzaju zmianami ich poglądów i zachowań. Zauważyłam, że na taką samą możliwość zwraca uwagę m.in. Alicja Czerkawska, opisując sytuację poradniczą jako formę pomocy i miejsce rozwiązywania problemów egzystencjalnych. Autorka wskazuje, że w sytuacji poradniczej zachodzi „,wiele dynamicznych procesów, w perspektywie których człowiek rozwija własny potencjał osobowy"11.

Uczestnikami mediacji często stają się osoby o wysokim potencjale, które doznały niepowodzeń w relacji z drugim człowiekiem. Te złe doświadczenia staja się powodem podjęcia próby poradzenia sobie z trudną sytuacja, a często też naprawienia nadszarpniętych relacji, więzi. Rozpoczynając rozmowy $\mathrm{w}$ ramach mediacji, każda $\mathrm{z}$ osób wchodzących $\mathrm{w}$ proces prezentuje jakieś nastawienie, po swojemu interpretując aktualną sytuację. Uczestnicy demonstrują określone zachowania. Stosunek do procesu wpływa na typ zachowania danej osoby, która odgrywając swoją rolę, może posługiwać się różnymi narzędziami psychologicznymi i komunikacyjnymi. W badanych procesach stosunek ludzi do udziału w nich, a co za tym idzie - podejmowane działanie i interwencja mediatora, różniły się, zwłaszcza że nastawienie do współnegocjujących niejednokrotnie całkowicie przekształcało się w trakcie rozmów pod wpływem nowych doświadczeń skonfliktowanych osób. Różnice w podejmowanych przez ludzi działaniach sprawiały, że proces często dynamicznie się zmieniał, wymagając od mediatora i wspomaganych dostosowywania się do przeobrażajacej się sytuacji. Tu także można znaleźć pewne analogie do poradnictwa.

$\mathrm{Na}$ charakter procesu poradniczego, jako zjawiska wieloznacznego i zmiennego, w którym wiele rzeczy jest trudnych do przewidzenia, które wymaga elastyczności i niestereotypowości działań, zwraca uwagę Alicja Kargulowa, która wskazuje też na „odrębne rodzaje stosunków społecznych”, jakie powstaja w procesie poradniczym. Autorka opisuje ich trzy typy w układzie „doradca-radzący się”. Są to: kooperacja, współdziałanie; współzawodnictwo, gra, walka, rywalizacja; korzystanie z pomocy na zasadzie wymiany-zakupu ${ }^{12}$.

Opracowane typologie zachowań negocjacyjnych $\mathrm{z}$ udziałem mediatora biora pod uwagę różne kryteria, w tym też rodzaj wytwarzających się stosunków społecznych. Leo Hawkins, Michael Hudson i Robert Cornall, przyjmując za Kennethem L. Thomasem i Ralphem H. Kilmannem stosunek do celu własnego i strony przeciwnej, wymieniają cztery podejścia mieszczące się na skali od ignorowania celu po jego pełną realizację: konfrontację, kooperację, unikanie, przystosowanie. Cel negocjacji natomiast może być widziany jako zysk obu stron, strata obu stron lub zysk jednej i strata drugiej strony ${ }^{13}$.

\footnotetext{
${ }^{11}$ A. Czerkawska, Poradnictwo egzystencjalne. Zatożenia - inspiracje - rozwiazania praktyczne, WN DSW, Wrocław 2013, s. 106.

${ }^{12}$ A. Kargulowa, Przeciw bezradności. Nurty - opcje - kontrowersje $w$ poradnictwie i poradoznawstwie, Wyd. UWr, Wrocław 1996, s. 138 i 109.

${ }^{13}$ L. Hawkins, M. Hudson, R. Cornall, Prawnik jako negocjator czyli jak efektywnie negocjować zagadnienia prawne, Dom Wydawniczy ABC, Warszawa 1994, s. 65.
} 
Jeśli strony konfliktu przychodzą na spotkanie, ponieważ czują się do tego przymuszone (np. przez skierowanie sprawy do mediacji przez sąd, przed którym nie miały odwagi przyznać, że nie potrzebują takich spotkań), prezentuja opór, a ich cel i sens podjętych działań ograniczają się często do zaspokojenia potrzeby mówienia o sobie, pokazania się w jak najlepszym świetle w oczach wspomagajacego - mediatora. Może chodzić o zdobycie akceptacji mediatora, próbę przekonania go do swoich racji i tego, że wina leży po drugiej stronie. Czasem chodzi o utwierdzenie się co do poprawności swojego postrzegania rzeczywistości przez zracjonalizowanie swoich działań. Zdarza się, że prezentowanie oporu jest spowodowane np. wieloletnim konfliktem, który stał się już treścią życia zaangażowanych w niego osób. Jeśli dochodzi do takiej sytuacji, człowiek nie daży do rozwiąania konfliktu i porozumienia, a wspólne spotkanie mediacyjne traktuje jak okazję do wyżycia się na drugiej stronie i udowadniania jej swoich racji, stosujac trudny do przerwania tok wypowiedzi. Wówczas trudno mówić o mediacji jako takiej, słuchaczem bowiem staje się nie tylko przeciwnik, lecz także wspomagający mediator. Druga strona konfliktu może również zaprezentować opór i przyjąć podobną strategię. W niektórych sytuacjach wcześniej prezentowany opór może oczywiście ustapić. Kiedy stosunek uczestników do procesu się zmienia, zaczynają dostrzegać możliwość znalezienia porozumienia i wtedy mediacja zaczyna toczyć się według nowego, innego scenariusza.

\section{TYPOLOGIA NASTAWIENIA DO PROCESU MEDIACJI}

Na podstawie danych zamieszczonych w dokumentach sądowych i własnych obserwacji postanowiłam opisać i zinterpretować typy nastawienia uczestników, jakie występują w procesie radzenia sobie z problemem zachodzącym w relacji: wspomagający - wspomagany (ofiara) - wspomagany (krzywdziciel). Analizując wypowiedzi badanych, obserwacje oraz to, co było przywołane w pamięci moich rozmówców i mojej, doszłam do wniosku, że nastawienie do procesu mediacji i zachowania ujawniane w jej trakcie moga przyjmować różne formy i stać się podstawą pewnej typologii. Istotnym zadaniem wydała mi się właśnie próba stworzenia typologii zachowań, pokazanie różnic między początkowo prezentowanym nastawieniem, i jego zmianą $\mathrm{w}$ trakcie procesu. Próbując odpowiedzieć na pytania, jacy ludzie uczestniczą w mediacjach i jaki jest ich stosunek do mediacji i całego procesu, dostrzegłam bowiem, że strony (osoby, zespoły negocjacyjne) podejmujące próbę rozwiązania problemu w procesie mediacji budują sytuację korzystania z pomocy w charakterystyczny dla siebie sposób. W rezultacie udało mi się dostrzec cztery typy nastawienia do udziału w mediacji prezentowane przez badanych. Podjęłam próbę nazwania „typów uczestników” prezentujących określone nastawienie i zachowania ujawniane podczas mediacji w sposób metaforyczny: aktywny entuzjasta, trzé́wy gracz, totalny konformista, kontestator absolutny. $\mathrm{Z}$ moich obserwacji wynika, że demonstrowany typ nie musi być stały. Pod wpływem nowych doświadczeń może się zmieniać i w trakcie procesu przechodzić w inny. 
Skonstruowaną typologię uczestników i ich sposoby budowania sytuacji korzystania z pomocy pokazuję, uwzględniajac: 1) sposoby nawiązywania rodzajów stosunków społecznych w sytuacjach poradniczych opisanych przez Alicję Kargulową ${ }^{14}$; 2) metody negocjowania wyróżnione przez Rogera Fishera, Williama Ury'ego i Bruce'a Pattona ${ }^{15}$ oraz 3 ) opracowanie Kennetha L. Thomasa i Ralpha H. Kilmanna ${ }^{16}$ uwzględniające stosunek negocjatorów do celu i innych osób w sytuacji konfliktowej.

\section{Schemat 1}

Typy uczestników mediacji

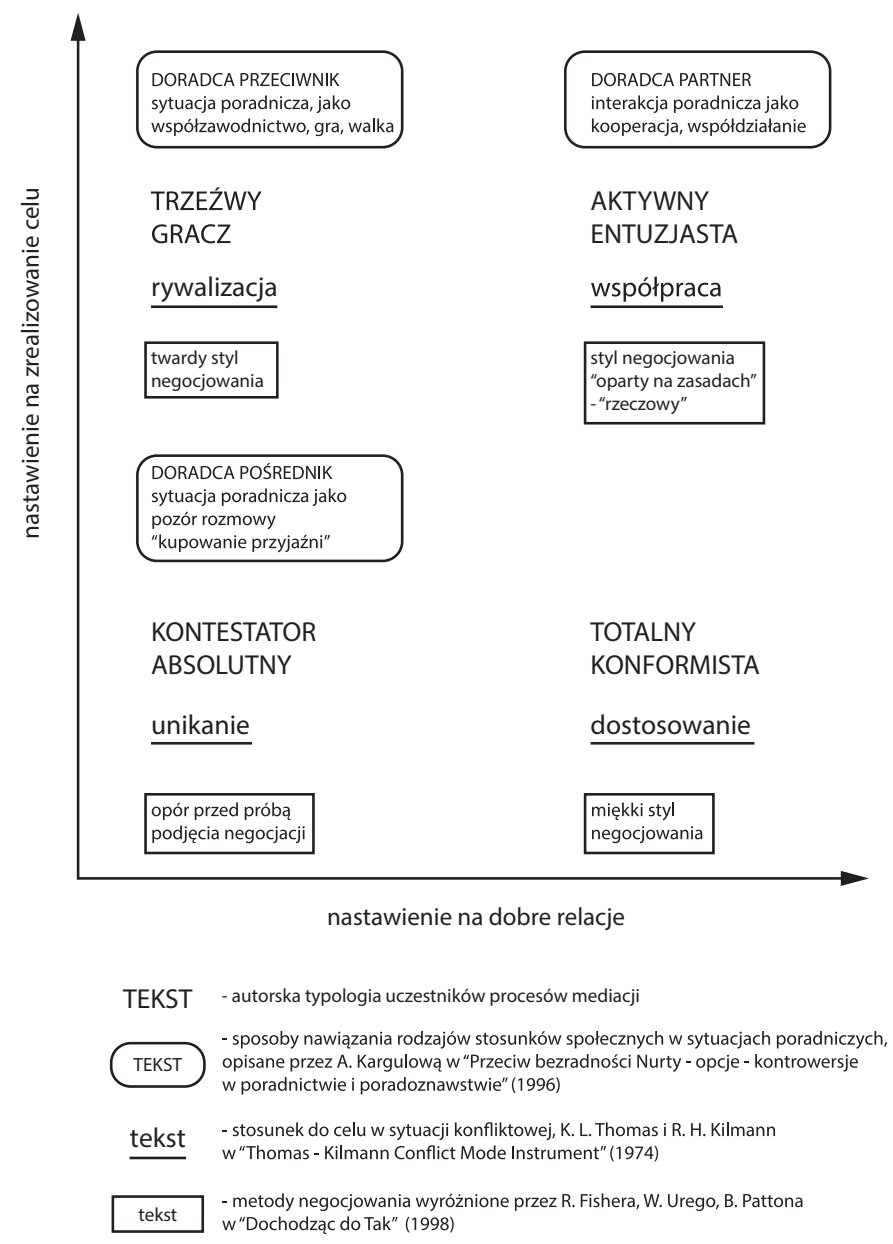

Źródło: opracowanie własne na podstawie literatury wskazanej w legendzie.

14 A. Kargulowa, op. cit.

${ }^{15}$ R. Fisher, W. Ury, B. Patton, Dochodzac do Tak. Negocjowanie bez poddawania się, PWE, Warszawa 1998.

${ }^{16}$ L. Thomas, R. H. Kilmann, Thomas - Kilmann Conflict Mode Instmment, Tuxedo, New York 1974. 
Aktywny entuzjasta traktuje innych uczestników procesu jak partnerów. Stara się współdziałać z nimi, by doprowadzić do rozwiązania problemu i wyjścia z trudnej sytuacji. Pisząc o współdziałaniu, A. Kargulowa podkreśla, że „chodzi w nim o ich [uczestników - dop. A.D.] bezpośrednie obcowanie, o nadawanie przez nich czytelnych informacji, świadczących o głównych intencjach partnerów, o ich gotowość do szczerej odpowiedzi na otrzymany sygnał, a także do osiagnięcia zamierzonych skutków [...]"17.

Zauważyłam, że współpracujący „aktywni entuzjaści” negocjowali w sposób zbliżony do, opisanej przez R. Fishera, W. Ury'ego i B. Pattona metody „negocjacji opartych na zasadach”18, kooperujacc i dążąc do wspólnego dobra. „Aktywny entuzjasta” rozwiązywał problem wspólnie z partnerem, poszukujacc rozsądnego, mądrego porozumienia. Ustępował ludziom, ale nie sprawom. Działał niezależnie od zaufania, koncentrując się na interesach zaangażowanych w rozmowy osób. Starał się rzeczowo rozmawiać i godzić te interesy, poszukując możliwości obustronnie korzystnych. Koncentrując się na problemie, w trakcie procesu przyjmował zasadne argumenty, ale nie ulegał presji. Współpraca i znalezienie optymalnego rozwiązania problemu w sytuacji korzystania z pomocy były możliwe wtedy, gdy obydwie strony cechowało pozytywne angażowanie się w rozmowy mediacyjne.

Podobna zależność zauważa A. Kargulowa, która uważa, że kooperacja i współdziałanie w sytuacji korzystania z pomocy opierają się na „pozytywnej interwencji radzącego się", która jest możliwa przy odpowiednich - umożliwiajacych to współdziałanie - cechach doradcy oraz takim poziomie zaufania wspomaganego, który implikuje jego otwartość i szczerośćc ${ }^{19}$. W procesie porady, w którym relacja zachodzi w układzie osoba wspomagajacca - osoba wspomagana czy osoba wspomagająca - osoba wspomagana - grupa wsparcia (w sytuacji pomocy grupowej), obdarzenie zaufaniem innych uczestników sytuacji oraz „odsłonięcie się” może przychodzić łatwiej niż w mediacji, kiedy to złe doświadczenia nadwerężyły zaufanie ludzi do siebie, a ich relacje uległy załamaniu. Od momentu powstania konfliktu do momentu spotkania się przy stole mediacyjnym niejednokrotnie mija dużo czasu. Konflikt najczęściej ulega znacznej eskalacji, a jego strony sa już skoncentrowane na „walce z drugim człowiekiem”. Decydujac się na spotkanie, czasami początkowo unikają swojego wzroku i nie są w stanie komunikować się w bezpośredni sposób. Siadajaccy przy jednym stole uczestnicy mediacji mogą przejść do konstruktywnych rozmów i wyjaśniania między sobą zagadnień i danych dopiero po obniżeniu (niejednokrotnie ostrych) emocji, po przejściu przez tzw. etap wentylacji (Lin$\operatorname{coln}^{20}$ ), po zbudowaniu przez wspomagającego - mediatora klimatu otwartości i wiarygodności oraz wytworzeniu odpowiedniej atmosfery sesji mediacyjnych sprzyjających burzeniu murów i budowaniu mostów między ludźmi. Widząc

17 A. Kargulowa, op. cit., s. 110-111.

18 R. Fisher, W. Ury, B. Patton, op. cit.

19 A. Kargulowa, op. cit., s. 110.

${ }^{20}$ Wentylacja jest trzecim etapem mediacji zgodnie z uporządkowaniem wg Billa Lincolna. Etapy mediacji wg Lincolna zamieszczone w: Z. Czwartosz, Techniki prowadzenia negocjacji $i$ mediacji. Materiaty pomocnicze dla stuchaczy studiów podyplomowych „Negocjacje $i$ mediacje”, SWPS, Warszawa 2001 (niepublikowane). 
akceptację, otwartość i chęć pomocy wspomagającego, negocjujące strony obdarzaja go zaufaniem. Dopiero teraz możliwa staje się ich wspólna „walka z problemem"- kooperacyjne formułowanie faktycznych problemów i współdziałanie w wypracowywaniu rozwiązania, pod warunkiem jednak, że obydwie strony tego chca. Celem ludzi jest wtedy porozumienie, a nawet pojednanie.

Trzeźwy gracz odbiera innych uczestników mediacji jako przeciwników. Drugą osobę traktuje jako przeszkodę w dążeniu do swojego celu. Dążąc do zwycięstwa, przyjmuje twardą metodę negocjacji ${ }^{21}$. Za wszelką cenę broni swojego stanowiska, niejednokrotnie stosując groźby. Żądając ustępstw i jednostronnych korzyści, jako warunku stosunków wzajemnych i możliwości porozumienia, nalega na przyjęcie swojego stanowiska. Ponieważ nie ufa innym, wywiera presję i stara się pokonać przeciwnika w walce na argumenty.

Podobna sytuacja może mieć miejsce w poradnictwie. A. Kargulowa pokazuje, iż możliwe jest, że relacje między partnerami w sytuacji poradniczej nie będą oparte na współpracy, a ułożą się właśnie jako gra-walka. Dzieje się tak wtedy, kiedy uczestnicy zinterpretują sytuację poradniczą jako sytuację rywalizacji między doradcą a - niezadowolonym z konieczności otrzymania pomocy - radzącym się, i najczęściej wynika to z chęci uzyskania przewagi nad partnerem w sposobie prowadzenia rozmowy ${ }^{22}$.

Zaangażowanie ludzi w rozmowy mediacyjne może być podyktowane oczekiwaniem na uzyskanie możliwej realnej korzyści i przedmiotowej satysfakcji przez realizację swoich interesów, związanych nie tylko z samą sytuacja mediacji. Pozostające w zależności osoby mogą bowiem sobie umożliwić (bądź uniemożliwić) zaspokojenie różnorodnych (emocjonalnych, materialnych, dotyczących uznania, zdrowia, znaczenia itp.) potrzeb, czy zdobycie pożądanych zasobów. Takie oczekiwanie po rozmowach gotowego produktu powoduje, że nie doceniają lub wręcz unikają możliwości odsłaniania się przed przeciwnikiem. Uczestnikom konfrontacji zbędna, a nawet niebezpieczna wydaje się zbyt duża otwartość i szczerość wypowiedzi. Zaczyna obowiązywać zasada ograniczonego zaufania i budowanie swojej taktyki negocjacyjnej w celu osiagnięcia określonej wartości. Strony konfliktu koncentruja się na reprezentowanym przez siebie stanowisku, by wywalczyć swoje rozwiązanie problemu. Potwierdza to Jan Waszkiewicz, który pokazuje, iż prezentując takie nastawienie, negocjatorzy żądają ustępstw, bronią swojego stanowiska za wszelką cenę, stosuja groźby, wywierają presję ${ }^{23}$.

Kiedy tak się dzieje, wspomagający - mediator interweniuje i usiłuje pokierować procesem tak, by okopane na pozycjach strony konfliktu zaczęły koncentrować się na interesach (a nie zajmowanych stanowiskach) i by dojrzały możliwa zbieżność celów. Kiedy uczestnikom sytuacji korzystania z pomocy udaje się ją dostrzec, a sytuacja układa się tak, że umożliwia podjęcie ryzyka otwarcia się i wzrost początkowo ograniczonego zaufania, czasem następuje przełamanie sporu i skonfliktowani uczestnicy zaczynają ze sobą współdziałać, kooperacyjnie radząc sobie z trudną sytuacją.

${ }^{21}$ Por. R. Fisher, W. Ury, B. Patton, op. cit., s. 43-44.

${ }^{22}$ A. Kargulowa, op. cit., s. 112.

${ }_{23}$ J. Waszkiewicz, Jak Polak z Polakiem. Szkice o kulturze negocjowania, Warszawa-Wrocław 1997, s. 198. 
Totalnemu konformiście do tego stopnia zależy na dobrych relacjach z osobami, z którymi pozostaje w konflikcie, że na wszystko się zgadza, przytakuje, przeprasza, nie troszcząc się o zrealizowanie celu i rezygnując z zaspokojenia swoich potrzeb. Jego styl udziału w rozmowach jest zbliżony do metody miękkiej negocjacji ${ }^{24}$. Ufa partnerowi - nawet gdy jest on krzywdzicielem w rozmowach traktujac go jak przyjaciela i ustępuje mu, by pielęgnować wzajemne stosunki. Chce się porozumieć za wszelką cenę, więc czyni ustępstwa, starając się być sympatycznym i delikatnym dla osoby będącej współuczestnikiem sytuacji korzystania z pomocy. Chce, by druga strona była zadowolona, więc ulega wywieranej przez nią presji, łatwo zmienia stanowisko i godzi się ze stratami dla dobra porozumienia.

Zaangażowanie „totalnego konformisty” w rozmowy podyktowane jest troską o aspiracje partnera - przyjaciela i zrealizowanie wytyczonego przez niego celu. Taki stosunek charakteryzuje niektórych uczestników mediacji będących w zwiąkach emocjonalnych z ludźmi, z którymi pozostaja w konflikcie. Sa to strony, które uznaja siebie za słabsze, drugiego - za silniejszego, a sytuację konfliktu - za wrogą i zagrażająca. "Totalni konformiści” dostosowują się do drugiej strony, chcąc jak najszybciej zakończyć spór i powrócić do „normalnej” znanej relacji, w której nauczyli się już funkcjonować. Zdarza się, że odkrywają potencjał konfliktu i udaje im się zobaczyć pozytywne jego strony. Konsekwencje „nowych”, podjętych w trakcie mediacji, działań stają się dla tych uczestników nowym doświadczeniem i wpływaja na modyfikację przed-rozumianych ${ }^{25}$ treści. Świeża definicja sytuacji przyjęta przez „totalnego konformistę” i druga stronę może pomóc uczestnikom mediacji poznać wcześniej niedostrzegane aspekty problemów, rozważyć różne ukryte założenia, które wcześniej nie były uwzględniane, czy wymusić poszukiwanie alternatywnych rozwiązań. Wtedy znalezienie się w tych trudnych okolicznościach może pobudzić negocjujące strony i zmotywować je do działania w kierunku zmiany niewygodnej sytuacji, w której pozostają od jakiegoś już czasu. Jeśli uda się przerwać niekorzystny tok myślenia w sytuacji konfliktowej i wyrównać siłę stron w trakcie mediacji, może dojść do zmiany i przesunięcia zachowania uczestników w kierunku działania kooperacyjnego.

Kontestator absolutny nie jest zainteresowany wyjściem z trudnej sytuacji życiowej. Nie zależy mu na przywróceniu pokojowych relacji, ale na pokazaniu swojej przewagi i zwycięstwie nad drugą strona. Wykazuje on nieufność wobec drugiej osoby, stanowczo obstaje przy swoim zdaniu i jest gotowy do ofensywnej obrony. Pojawienie się na spotkaniu mediacyjnym jest dla niego sposobem zachowania pozorów poszukiwania możliwości skorzystania z pomocy. Tak naprawdę spotkanie ze wspomagającym mediatorem i drugim wspomaganym służy innym celom.

O takiej specyficznej formie pomocy poradniczej i budowaniu sytuacji korzystania z pomocy na zasadzie wymiany-zakupu pisze A. Kargulowa. Autorka nazywa tę sytuację „kupowaniem przyjaźni” i pokazuje, że „zanika tu skom-

\footnotetext{
${ }^{24}$ Por. R. Fisher, W. Ury, B. Patton, op. cit., s. 43-44.

${ }^{25}$ Termin w socjologicznej teorii interakcjonizmu symbolicznego. „Przed-rozumienia”, stanowiące nieodłączny element świata społecznego, sa formą uczestniczenia w nim i jego doświadczaniu. Determinują one zdolność do rozumienia innych i porozumienia.
} 
plikowane budowanie sytuacji, uzgadnianie wartości, zdobywanie zaufania, definiowanie roli partnera". Mamy do czynienia z pozorem rozmowy, która sprowadza się do zakupienia życzliwego słuchacza - „doradcy-pośrednika”, przed którym radzący się może się wygadać, wyrzucając swoje niepokoje, rozterki i racjonalizując z góry zaplanowane przeżycia ${ }^{26}$.

Z moich badań wynika, że niektórzy uczestnicy mediacji także uznawali udział w niej za dopełnienie niezbędnej formalności. Prezentowana taktyka, często podyktowana indywidualnymi możliwościami i ograniczeniami, pomagała wówczas w utrzymywaniu dystansu w konfrontacji ze skonfliktowaną z nimi osoba. Uczestnicy badanych mediacji przeważnie jednak ujawniali zachowania typowe dla wyróżnionych przez A. Kargulową dwóch pierwszych rodzajów stosunków społecznych w procesie poradniczym i zachowywali się kooperacyjnie lub rywalizacyjnie, gdy prezentowali opór. Byli jednak i tacy, którzy postępowali cynicznie, gdy nie dążyli do rozwiązania konfliktu, a chodziło im o poniżenie przeciwnika, zwłaszcza wówczas gdy ten dążył do ugody za wszelką cenę.

\section{PRZEMIANY NASTAWIENIA DO MEDIACJI}

Specyficzna formuła mediacyjnych spotkań toczących się w układzie wspomagajaccy - wspomagany (ofiara) - wspomagany (krzywdziciel) ujawniła jeszcze jeden stosunek badanych do procesu - wyrażajacy się w sposobie zachowania opartym na dostosowywaniu się. Został on uwzględniony przez K. L. Thomasa i R. H. Kilmanna ${ }^{27}$ jako jeden ze stosunków do celu przyjętego w sytuacji konfliktowej. Klasyfikacja uczestników mediacji i ich sposobu budowania sytuacji korzystania z pomocy pokazuje dostrzeżone przez badacza nastawienia do samego procesu. Każda z osób wpisuje się w któryś z typów budowania sytuacji korzystania z pomocy, rozpoczynając rozmowy, ale stosunek do niej i pozostałych uczestników może przechodzić w inny pod wpływem nowych doświadczeń. A oto zależności, jakie zauważyłam w badanych procesach.

Kiedy obydwie strony prezentowały opisany wyżej typ ,aktywnego entuzjasty", bardzo zależało im na rozwiązaniu problemu i wyjściu z trudnej sytuacji życiowej. Pragnęły one zrealizowania swojego celu, ale dbały też o dobre stosunki z partnerem i jego zadowolenie. Takie nastawienie stawało się podstawa dla pełnego rozwiąania problemu, porozumienia, a nawet pojednania zwaśnionych stron i skutkowało pełną transformacją sytuacji życiowej, nawet jeżeli uczestnicy nie zdawali sobie z tego sprawy.

Dostrzeżony wśród badanych typ „kontestatora absolutnego” demonstrował opór przed próbą rozwiązania konfliktu. Uczestnicy prezentujący takie nastawienie z różnych przyczyn czerpali korzyść psychologiczną z zaangażowania się w podtrzymywanie obecnej zaognionej relacji. Osoby te często podejmowały rozmowy, czując się do tego przymuszone. Przystapienie do rozmów i otwarcie się na tę formę pomocy okazywało się pozorem. Celem była walka z druga stroną oraz chęć zdobycia „słuchacza”. Udział dwóch „kontestatorów

\footnotetext{
26 A. Kargulowa, op. cit., s. 115-119.

27 K. L. Thomas, R. H. Kilmann, op. cit.
} 
absolutnych" w procesie był równoznaczny z próbą stworzenia teatru jednego widza, w której to roli chcieli oni postawić wspomagającego.

Jeśli natomiast jedna ze stron prezentowała typ „aktywnego entuzjasty”, a druga - niezłomnego „kontestatora absolutnego”, ten drugi pozór dobrej woli porozumienia potrafił utrzymywać aż do momentu podpisania ugody, z której to, nawet w ostatniej chwili, potrafił się wycofać. Zdarzało się jednak, że pod wpływem nowych doświadczeń w trakcie mediacji opór ustępował. Następowało to jednak tylko w sytuacji sprowadzenia konfliktu do płaszczyzny konfliktu interesów i zmiany interpretacji sytuacji, co pomagało rozpocząć walkę z problemem, a zakończyć walkę z ludźmi. Wtedy „kontestator absolutny” zmieniał się w „aktywnego entuzjastę” lub też, widząc coś ważnego do „ugrania" i prezentujacc ograniczone zaufanie do drugiej strony, zaczynał działać jak „trzeźwy gracz”.

„Trzeźwy gracz”, stosujacy twardy styl negocjowania, przeważnie oczekiwał przedmiotowej satysfakcji z osiagnięcia przedsięwziętego celu. Jego stosunek do drugiej strony i procesu był przeważnie instrumentalny i żądaniowy. W badanych procesach dwóch „trzeźwych graczy” czasem jednak potrafiło wypracować kompromisowe rozwiązanie problemu i utrzymać w miarę poprawne relacje z druga stroną. Bywało tak, że jeśli jeden ze wspomaganych potrafił zmienić swoje nastawienie i podejmował próbę współpracy, wskazując na możliwe wspólne cele, a drugą stronę stać było na kredyt zaufania, to uczestnicy procesu zaczynali kooperować. Stawali się „aktywnymi entuzjastami” i zmieniali styl negocjacji z twardego na rzeczowy, współpracujacc ze sobą w wypracowaniu rozwiązania. Druga strona zaczynała być wówczas postrzegana jako partner, a nie przeciwnik, jak było na początku procesu korzystania z pomocy.

W badanych przypadkach „totalny konformista”, w przeciwieństwie do „trzeźwego gracza”, stosował „miękką” metodę negocjowania. Traktował ludzi i problem bardzo delikatnie, nie chcąc się narazić na pogorszenie relacji bądź zagrożenie porozumienia. Jeśli drugi wspomagany prezentował typ uczestnika inaczej budujacego proces korzystania z pomocy, to „totalny konformista” był zawsze słabszą strona konfliktu. W takich sytuacjach wspomagajacy zwykle starał się podjaćc próbę wyrównania siły pomiędzy negocjatorami. Jeśli udawało mu się wesprzeć „totalnego konformistę”, ten potrafił zmienić swój stosunek na bardziej roszczeniowy i podjać współpracę z chętnym do tego „aktywnym entuzjasta". W poddanych analizie procesach nie pojawił się przypadek przejścia z typu „totalnego konformisty” do typu „trzeźwego gracza”. Moim zdaniem niemożność podjęcia rywalizacji przez uczestników prezentujących typ „totalnego konformisty” była związana z długo demonstrowanym przez nich nastawieniem na utrzymywanie dobrych relacji i postrzeganie wspólnej płaszczyzny problemu z jednocześnie występujacca małą troską o wyłącznie swoje aspiracje. Nagła zmiana nastawienia na skrajnie inne okazywała się niemożliwa.

W sytuacji gdy wspomagany prezentujący najbardziej optymalny dla rezultatu negocjacji typ „aktywnego entuzjasty” spotyka się z niezłomna roszczeniową i instrumentalną postawą "trzeźwego gracza” prezentowana przez druga stronę, sposób budowania sytuacji korzystania z pomocy z pierwotnego 
kooperacyjnego może się zmienić w rywalizację typową dla „trzeźwego gracza” lub też w opór typowy dla „kontestatora absolutnego”.

Pierwotny „aktywny entuzjasta” przekształcony w typ „trzeźwego gracza” stosującego twardy styl negocjowania, tracąc nadzieję na osiagnięcie przedsięwziętego celu, może zaczać prezentować opór i walczyć z drugą stroną. W takich sytuacjach często dochodzi do przerwania rozmów, które na ogół nie pozostawiaja nadziei na polubowne wypracowanie rozwiązania trudnej sytuacji.

Zmiany zachodzace w stylach uczestniczenia w mediacji przedstawia schemat 2 .

\section{Schemat 2}

Możliwości zmiany typu uczestnika mediacji

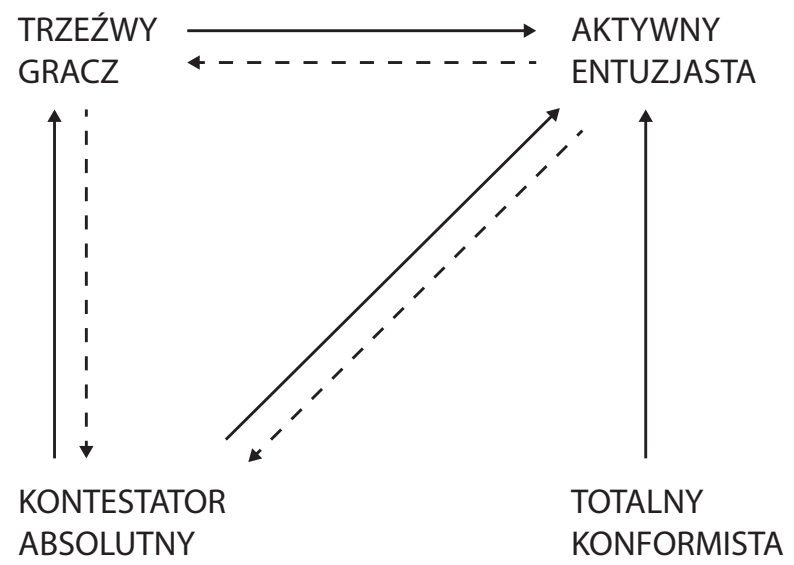

Źródło: opracowanie własne.

Mediatorzy, którzy byli moimi rozmówcami, przyznawali, że nastawienie prezentowane przez strony w różnym stopniu i kierunku, ale prawie zawsze się zmienia. Doświadczeni mediatorzy uważali, że nastawienie prezentowane przez uczestników mediacji jest podyktowane w części cechami osobowościowymi, oczekiwaniami co do rezultatu rozmów oraz przyjętą przez wspomaganych definicją sytuacji, ale również prezentowaną przez uczestników wiedzą na temat mediacji jako procedury rozwiązywania konfliktów. Twierdzili, że duże znaczenie ma to, czy uczestnicy mediacji są „zorientowani w sytuacji” i czy moga planować swoje działania. Mediatorzy podkreślali, że jeżeli uczestnicy „nie wiedza”, „nie rozumieja”, to nie czują się komfortowo i nie są nastawieni pozytywnie do próby polubownego rozwiązania sporu czy konfliktu. Przyznawali, że dużą wartość mają pozytywne wcześniejsze doświadczenia oraz wiara w to, że można znaleźć rozwiązanie toczącego się sporu i uniknąć procesu sądowego. Moi rozmówcy zwracali uwagę na rolę pełnomocnika prawnego, który może dobrze się czuć w nieformalnych procedurach i poma- 
gać w dojściu do porozumienia swego mocodawcy i drugiej strony w drodze mediacji lub to utrudniać, a nawet uniemożliwiać. Duże znaczenie ma fakt wspólnoty interesów pełnomocnika i jego mocodawcy.

Mediatorzy, przyglądając się przedstawionej typologii uczestników mediacji, wskazywali, że konstrukt ten może pomóc praktykom porządkować myślenie o stylu działania stron oraz przewidywać ich zachowania w sytuacji negocjacji, a także planować kierunek podejmowanych działań.

Przyznawali, że nazwy określające uczestników mediacji są obrazowe i pozwalają na szybkie - skrótowe - zdefiniowanie sytuacji i typu zachowania wspomaganych uczestników mediacji oraz możliwości ich zmiany.

\section{ZAKOŃCZENIE}

Z opisów dokonywanych przez bezpośrednich jej uczestników można wnioskować, że mediacja, która z założenia ma pomóc w porozumieniu się w jednej sprawie, poradzeniu sobie wspomaganych z jednym, konkretnym problemem może mieć znaczne konsekwencje psychologiczne i zwiększać umiejętności sprzyjające samodzielnemu pokonywaniu pojawiających się kolejnych trudności i rozwiązywaniu problemów społecznych.

Ogólnie można zauważyć, że nastawienie (osób uczestniczących w procesie mediacji) do siebie, do drugiej strony, przedmiotu sporu i do pomocy mediatora - determinowało sposób radzenia sobie z konfliktem. Każda z osób, rozpoczynając rozmowy, wpisywała się w któryś z typów budowania sytuacji korzystania z pomocy, a jej stosunek do całego procesu i pozostałych uczestników mógł przechodzić w inny pod wpływem nowych doświadczeń. Prezentowanie się jako określony typ uczestnika mediacji, związane z określonymi zachowaniami w sytuacji konfrontacji, decydowało o transformacji oceny sytuacji i nabyciu nowych doświadczeń życiowych.

Badani narratorzy czasem dostrzegali długofalowe rezultaty udziału $\mathrm{w}$ mediacji, a zmiany $\mathrm{w}$ życiu traktowali jako konsekwencje tego wydarzenia. Niektórzy z nich zauważyli, spoglądając z perspektywy własnej biografii, zmiany w sposobie interpretowania otaczającego ich świata oraz swoim zachowaniu po spotkaniach mediacyjnych z drugą stroną. Uczestniczenie $\mathrm{w}$ procesie mediacji oceniali jako ważne wydarzenie życiowe. Podkreślali rolę tego doświadczenia, które - ich zdaniem - miało sens i zaowocowało nie tylko zmianami w codziennym postępowaniu, ale także przełożyło się na funkcjonowanie i relacje interpersonalne $\mathrm{w}$ ich dalszym życiu. Ujmując to metaforycznie, można więc powiedzieć, że udział w mediacji pomógł niektórym jej uczestnikom wprowadzić poprawki do odgrywanej przez nich roli i zmienić zapis w ich życiowym scenariuszu. Tylko wśród nieugiętych „kontestatorów absolutnych” i „totalnych konformistów” nie można zauważyć elementów transformacji doświadczeń życiowych. Prezentowanie tego typu nastawienia przez strony można zaobserwować w konfliktach, które nie pozostawiały szansy na ich rozwiązanie w drodze mediacji. Charakteryzując konflikty nierozwiąywalne, Daniel Bar-Tal stwierdza, że istotnym czynnikiem ich trwania jest podziela- 
nie przekonań że: dążenia nie mogą być przedmiotem kompromisu, nie można zaufać rywalowi, „zasoby ludzkie i materialne” są wystarczające, by wygrać z drugą strona konfliktu, a czas działa na naszą korzyśśc ${ }^{28}$.

Chęć zakończenia konfliktu przez strony jest ważną okolicznościa, znaczącą dla losów sprawy. Z analizy badanych procesów mediacji wynika, że czynnikami znacznie zwiększającymi szanse porozumienia były: po pierwsze zmęczenie długo trwającym konfliktem, które sprawiało, że pojawiała się gotowość do kompromisu i słabło przywiązanie do prezentowanych przez strony stanowisk (wtedy uczestnicy mediacji często werbalizowali chęć podjęcia rozmów i zakończenia, zamknięcia sprawy); po drugie - moment przełamania z nastawienia na „moją” wygrana i traktowania adwersarza jako przeciwnika. $\mathrm{W}$ analizowanych procesach wszystko się zmieniało, kiedy któryśs z uczestników mediacji zaczynał traktować drugą stronę jako partnera i przestawał widzieć sytuacje jako zero-jedynkowa. Wymienione okoliczności zdecydowanie pomagały poradzić sobie z przeciągajaccą się trudną sytuacją interpersonalną i powrócić do poprawnych relacji.

dr Agnieszka Dragon

Uniwersytet Wroctawski

agnieszka.dragon@uwr.edu.pl

\section{THE MEDIATION PROCESS. TYPOLOGY OF MEDIATION PARTICIPANTS AND CHANCES FOR A CONSENSUS}

\section{Summary}

This paper is an analysis of mediation, in which special focus was put on the creativity of individuals in the world of social meanings. The typology of mediation participants and the ways in which they build a situation is presented, including: (i) types of social relations in advisory situations as described by Alicja Kargulowa; (ii) Roger Fisher's, William Ury's and Bruce Patton's method of negotiations; and (iii) the work by Kenneth L. Thomas and Ralph H. Kilmann in which the relation between negotiators and the purpose of mediation, or the attitude of negotiators to its purpose and other participants of a conflict situation have been taken into account. This different approach to mediation allows the reader to see other aspects of the procedure. Contrary to the criminal trial, the vision of mediation presented here reveals that the settlement arrived at by the parties is not the only benefit of the procedure, as it does not only focus on facts but also on relationships and the interests of the parties.

Looking at the process of mediation through the prism of the negotiating parties may be an inspiration and raise awareness. It also serves to ensure openness to the philosophy of restorative justice.

${ }^{28}$ D. Bar-Tal, Podstawy kulturowe i dynamika nierozwiazywalnych konfliktów: podejście socjopsychologiczne, „Psychologia Społeczna” 8, 2013, nr 1(24), s. 8. 